\title{
Evaluation of chemical weed control options in broadcast and drill sown direct seeded rice
}

Muhammad Usman Ibrahim ${ }^{1 *}$, Rana Nadeem Abbas ${ }^{1}$, Zubair Aslam ${ }^{1}$, Ali Ahmad ${ }^{1}$, Anser Ali ${ }^{3}$, Ghulam Akbar ${ }^{4}$, Mehwish Nadeem², Irum Yousaf $^{2}$ and Wajeeh ur Rehman ${ }^{1}$

1. Department of Agronomy, University of Agriculture Faisalabad, 38000-Pakistan

2. Department of Botany, University of Agriculture Faisalabad, 38000-Pakistan

3. Department of Agronomy, Ghazi University, Dera Ghazi Khan-Pakistan

4. Department of Biochemistry, University of Agriculture Faisalabad, 38000-Pakistan

*Corresponding author's email: mmusman433@gmail.com

Citation

Muhammad Usman Ibrahim, Rana Nadeem Abbas, Zubair Aslam, Ali Ahmad, Anser Ali, Ghulam Akbar, Mehwish Nadeem, Irum Yousaf and Wajeeh ur Rehman. Evaluation of chemical weed control options in broadcast and drill sown direct seeded rice. Pure and Applied Biology. Vol. 9, Issue 2, pp1473-1480. http://dx.doi.org/10.19045/bspab.2020.90152

Received: 19/12/2019 Revised: 26/02/2020

Accepted: 05/03/2020

Online First: 10/03/2020

\section{Abstract}

Being a resource conservation technology under rice-wheat cropping system, increasing water crisis, lack and high cost labor forced grower to grow rice directly into the field called as direct seeded rice (DSR). High weed infestation impeded the adoption of direct seeded rice by farmers. Various tillage practices, stale seed bed, best selection of competitive rice cultivar, water management, hand weeding and mechanical weeded are components strategies to control weeds in DSR. In this perspective, one option to control weeds through herbicides. Therefore, a field study was conducted to evaluate the efficacy of pre and post emergence herbicides under different sowing methods. Application of bispyribac-sodium + benzsulfuron methyl as post-emergence (POST) following pre herbicides (Ethoxysulfuron ethyl) or as tank-mixture with bispyribacsodium + benzsulfuron methyl and Oxadiargyl effectively reduced the density and biomass accumulation of diverse weed flora in DSR. High grain yield and 1000 grain weight was recorded in the same treatment under drill sown method of rice plantation. It has been concluded that bispyribac-sodium + benzsulfuron ethyl as post-emergence (POST) following PRE herbicides (Ethoxysulfuron ethyl) or as tank-mixture with bispyribac-sodium + benzsulfuron and Oxadiargyl not only reduce weed biomass and density but also increase the total number of tillers, plant height, number of grains per panicle, 1000 grain weight and grain yield under drill sown method of DSR. The objective of present study was to examine the efficacy of different herbicides applied alone or in sequence to reduce weeds infestation in broadcast and drill sown direct seeded rice.

Keywords: Direct seeded rice; Herbicides; PRE; POST; Weed management

\section{Introduction}

Rice (Oryza sativa L.) is important staple food for more than half of the population [1].
About $90 \%$ of the world's rice is produced and consumed in Asia [2]. Being one of the important source of foreign earning, it consist 
$60 \%$ coarse and $40 \%$ fine. Global warming scare water resources, limited availability of labor and climate change threaten the rice productivity through conventional method of cultivation [3]. In response to water and labor shortage, some alternative options are suggested by researcher such as direct seeded rice (DSR) cultivation $[4,5]$. DSR is an emerging technology for water conservation that is governed by the direct placement of seeds in the submergence, non-puddled and unflooded field [6-8]. Many advantages of DSR over transplanted rice has been reported in literature as require less water and labor [911]. [12] reported that aerobic rice require $44 \%$ less water that conventional rice through reducing the losses of percolation, evapotranspiration and seepage to achieve maximum level of yield. The main challenge for successful DSR cultivation is heavy weed infestation due to aerobic conditions in the field [13-15]. Nearly 70-80\% yield losses are expected due to weed infestation in direct seeded rice [16-18]. The best approach to control weeds in DSR is application of various herbicides but the efficacy is not still satisfactory due to narrow spectrum behavior of applied herbicides [15, 19]. [20] reported that post-emergence application of bispyribac sodium $25 \mathrm{~g} / \mathrm{ha}$ is helpful to control a diverse range of weeds in rice. Direct seeded rice is an emerging technology for water conservation that is goverened by

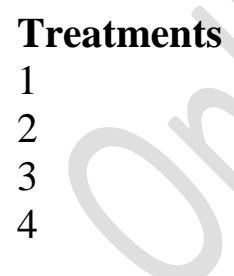

5

Herbicides treatments

Control (Weedy Check)

Ethoxysulfuron Ethyl 60\% WG

Bispyribac Sodium + Bensulfuron methyl 30\% WP

Ethoxysulfuron ethyl and Bispyribac

Sodium + Bensulfuron methyl

Bispyribac Sodium + Bensulfuron

Methyl + Oxadiargyl 80\% WP the direct placement of seeds in the submergence, non-puddled and unflooded field [6-8]. [21] studied various sowing methods with different agronomic practices for aerobic rice cultivation. They stated that yield of drill sown method of direct seeded rice cultivation technique was much higher than broadcasting. [22] stated that the row to row and plant to plant distance $22.5 \times 22.5$ $\mathrm{cm}^{2}$ is appropriate for good crop stand establishment, higher number of tillers and final yield of crop. Good weed control practices and crop establishment are the main factors in successful aerobic rice production [7].

\section{Materials and methods \\ Study location}

Field experiment were conducted at Agronomic research Area, university of Agriculture, Faisalabad during the kharif season 2016. The soil texture was sandy loam in texture and low in organic matter $(0.34$ $0.37 \%$ ) with alkaline in nature.

\section{Experimental design and treatments}

The experiment laid out in randomized complete blocked design (RCBD) with three replications using drill and broadcast method of sowing. Herbicides included in the study were Ethoxysulfuron ethyl (Sunstar gold, Syngenta), bispyribac sodium+ benzsulfuron methyl (Winsta, Bayer) and Oxadiargyl (Topstar, Syngenta).

\section{Application time}

12h DAS

35 DAS

12h DAS and 35 DAS

35 DAS

\section{Experimental details}

The crop planted during second week of June, 2016 using two sowing methods viz: broadcast and drill method in the agro ecological zone of Faisalabad, Punjab, Pakistan. Tractor mounted drill were used for drill sowing while, broadcast manually in both sowing methods. Seed rate used at $20 \mathrm{~kg}$ 
$\mathrm{ha}^{-1}$ in both sowing methods. Pre-emergence application of ethoxysulfuron ethyl (preemergence) were made with 24 hours of sowing. While, application of bispyribac sodium + benzsulfuron methyl (postemergence) herbicides were done 35 days after sowing. Similarly, oxadiargyl (postemergence) were applied in combination with bispyribac sodium + benzsulfuron methyl (post emergence) at 35 DAS. The herbicides were applied using a knapsack sprayer fitted with a flat-fan nozzle and calibrated to deliver $500 \mathrm{~L} \mathrm{ha}^{-1}$ for pre spray and $375 \mathrm{~L} \mathrm{ha}^{-1}$ for post spray. The area of each plot was $28 \mathrm{~m}^{2}(7 \times 4 \mathrm{~m})$. The crop was managed following the standard recommended practices for the region. Recommended dose of fertilizers, 46:35:25 NPK ha ${ }^{-1}$, were applied. Half dose of $\mathrm{N}$ and full dose of $\mathrm{P}$ and $\mathrm{k}$ were applied at the time of sowing. Remaining amount of $\mathrm{N}$ was applied in two splits at 40 and 60 DAS. After the first irrigation at the time of seeding, the second light irrigation was applied 5 DAS. Subsequent irrigations were provided at a weekly interval. Irrigations were applied at 3-4 days interval at tillering stage and during panicle emergence. Weed biomass and weed density was determined at 60 DAS from a randomly selected $2 \mathrm{~m}^{2}$ quadrat in each plot. Weed samples were oven dried before weighing at $70{ }^{\circ} \mathrm{C}$ till the constant weight was achieved. At harvesting, five rice plant clusters were randomly selected from each treatment to collect data for plant height $(\mathrm{cm})$, panicle length $(\mathrm{cm})$, and number of grains per panicle. Tillers with filled grains were recorded from $2 \mathrm{~m}^{-}$ 2 area for each treatment at harvesting. The crop was harvested in the second week of November, 2016, at both sites from two spots $(1 \times 1 \mathrm{~m}$ and $3 \times 3 \mathrm{~m})$ area per treatment for accuracy and averaged.

\section{Results and discussion Weed density and biomass}

Common weed species infesting the experimental site during study were horse purslane (Trianthema portulacastrum L.), crowfootgrass (Dactyloctenium aegyptium L.), goosegrass (Eleusine indica L.), and sedges (Cyperus spp.). There was a significant interaction between the herbicide application and sowing methods. Minimum weed density and biomass was recorded under the application of bispyribac-sodium + benzsulfuron methyl as post-emergence (POST) following PRE herbicides (Ethoxysulfuron ethyl) or as tank-mixture with bispyribac-sodium + benzsulfuron methyl and Oxadiargyl treatments under drill sown method of DSR as shown in (Fig. 1a, b). While, maximum weed density and biomass was recorded where no application was done. The effectiveness of bispyribac sodium as a post emergence herbicide for DSR is also reported by $[17,23]$. The findings of present study corroborate the previous findings of [16, 23-25] who concluded that herbicides are an effective mean of securing yield loss against weed infestation during critical period.

\section{Plant height (cm)}

In (Table 1) reveals significant $(\mathrm{p} \leq 0.05)$ effect of herbicides application on plant height under broadcast and drill sown direct seeded rice. The individual effect of herbicides and sowing methods was statistically significant. However, the interaction between herbicides $\times$ sowing methods was found statistically nonsignificant ( $\mathrm{p} \leq 0.05)$. Application of bispyribac-sodium + benzsulfuron methyl as post-emergence (POST) following PRE herbicides (Ethoxysulfuron ethyl) increased plant height $(88.49 \mathrm{~cm})$. However, plant height was recorded statistically nonsignificant in both sowing methods. These results corelates with the finding of [26] who 
concluded that application of herbicides encourages increased plant height.

Total number of tillers $\left(\mathrm{m}^{-2}\right)$

In (Table 1$)$ suggested significant $(\mathrm{p} \leq 0.05)$ effect of herbicides application on total number of tillers under broadcast and drill sown direct seeded rice. The individual effect of herbicides and sowing methods was statistically significant. However, the interaction between herbicides $\times$ sowing methods was found statistically nonsignificant $\quad(p \leq 0.05)$. Application of bispyribac-sodium + benzsulfuron methyl as post-emergence (POST) following PRE herbicides (Ethoxysulfuron ethyl) increase the total number of tillers $\left(506.67 \mathrm{~m}^{-2}\right)$. However, maximum number of tillers was recorded under drill sown method of direct seeded rice.
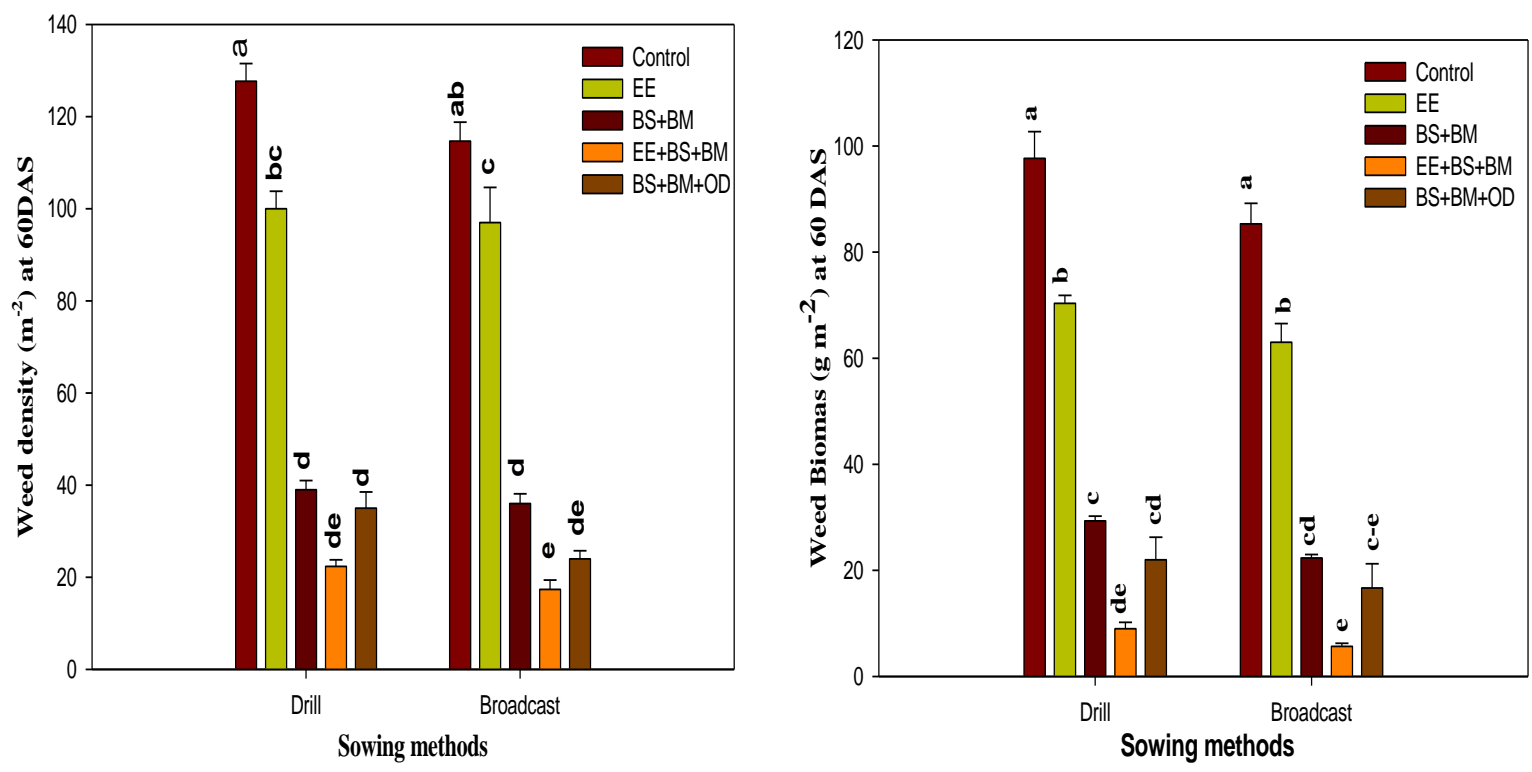

Figure (1a, b). Effect of herbicide application and sowing methods on total weed density and weed biomass $\left(\mathrm{m}^{-2}\right)$ at 60 DAS

Total number of productive tillers $\left(\mathrm{m}^{-2}\right)$

In (Table 1$)$ and reveals significant $(p \leq 0.05)$ effect of herbicides application on total number of tillers under broadcast and drill sown direct seeded rice. The individual effect of herbicides and sowing methods was statistically significant. However, the interaction between herbicides $\times$ sowing methods was found statistically nonsignificant ( $\mathrm{p} \leq 0.05)$. Application of bispyribac-sodium + benzsulfuron methyl as post-emergence (POST) following PRE herbicides (Ethoxysulfuron ethyl) increased total number of tillers $\left(506.67 \mathrm{~m}^{-2}\right)$. While, minimum number of tillers was recorded under drill sown direct seeded rice. These results are same with the findings of [27] who reported that high weed infestation reduces the number of tillers

Total number of productive tillers $\left(\mathrm{m}^{-2}\right)$

In (Table 1) reveals significant $(\mathrm{p} \leq 0.05)$ effect of herbicides application on total number of productive tillers under broadcast and drill sown direct seeded rice. The individual effect of herbicides and sowing methods was statistically significant. However, the interaction between herbicides $\times$ sowing methods was found statistically non-significant $(p \leq 0.05)$. Application of bispyribac-sodium + benzsulfuron methyl as post-emergence (POST) following PRE herbicides (Ethoxysulfuron ethyl) increase 
the total number of productive tillers (481.67 $\mathrm{m}^{-2}$ ). However, maximum number of productive tillers was recorded under drill sown direct seeded rice. The same results were reported by [23].

Table 1. Effect of different herbicides application and sowing methods on yield attributes of rice crop

\begin{tabular}{|c|c|c|c|c|c|c|}
\hline $\begin{array}{l}\text { Weed Control } \\
\text { Treatments }\end{array}$ & $\begin{array}{l}\text { Plant } \\
\text { height } \\
(\mathbf{c m})\end{array}$ & $\begin{array}{c}\text { Total } \\
\text { number of } \\
\text { tillers }\left(\mathbf{m}^{-2}\right)\end{array}$ & $\begin{array}{l}\text { Total } \\
\text { number of } \\
\text { productive } \\
\text { tillers }\left(\mathbf{m}^{-2}\right)\end{array}$ & $\begin{array}{l}\text { Total number } \\
\text { of } \\
\text { unproductive } \\
\text { tillers }\left(\mathrm{m}^{-2}\right)\end{array}$ & $\begin{array}{c}1000 \\
\text { kernal } \\
\text { weight }\end{array}$ & $\begin{array}{c}\text { Kernal } \\
\text { yield }(\mathbf{t} \\
\left.\text { ha }^{-1}\right)\end{array}$ \\
\hline Weedy Check & $72.28 \mathrm{C}$ & $338.67 \mathrm{C}$ & $282.83 \mathrm{C}$ & $55.83 \mathrm{~A}$ & $15.50 \mathrm{D}$ & $1.83 \mathrm{E}$ \\
\hline $\begin{array}{l}\text { Ethoxysulfuron ethyl } \\
\text { (PRE) }\end{array}$ & $\begin{array}{l}76.90 \\
\mathrm{BC}\end{array}$ & $378.00 \mathrm{BC}$ & $325.83 \mathrm{C}$ & $52.16 \mathrm{~A}$ & $17.83 \mathrm{C}$ & $2.20 \mathrm{D}$ \\
\hline $\begin{array}{c}\text { Bisypribac Sodium + } \\
\text { Bensulfuron methyl } \\
\text { (POST) }\end{array}$ & $79.08 \mathrm{~B}$ & $431.33 \mathrm{BC}$ & $416.50 \mathrm{~B}$ & & $19.66 \mathrm{~B}$ & $3.06 \mathrm{C}$ \\
\hline $\begin{array}{c}\text { Ethoxysulfuron ethyl } \\
\text { (PRE) + Bisypribac } \\
\text { Sodium + } \\
\text { Bensulfuron methyl } \\
\text { (POST }\end{array}$ & $88.48 \mathrm{~A}$ & $506.67 \mathrm{~A}$ & $481.67 \mathrm{~A}$ & $25.00 \mathrm{D}$ & $22.00 \mathrm{~A}$ & $3.45 \mathrm{~A}$ \\
\hline $\begin{array}{c}\text { Bisypribac Sodium + } \\
\text { Bensulfuron methyl + } \\
\text { Oxadiargyl (POST) }\end{array}$ & $\begin{array}{c}82.70 \\
\mathrm{AB}\end{array}$ & $455.33 \mathrm{AB}$ & $394.33 \mathrm{~B}$ & $31.00 \mathrm{C}$ & $\begin{array}{c}21.00 \\
\mathrm{AB}\end{array}$ & $3.28 \mathrm{~B}$ \\
\hline LSD Value & 7.79 & 83.12 & 85.87 & 9.87 & 1.98 & 0.09 \\
\hline \multicolumn{7}{|l|}{ Sowing Methods } \\
\hline Dry sowing with drill & $81.70 \mathrm{~A}$ & $445.60 \mathrm{~A}$ & $403.07 \mathrm{~A}$ & $42.53 \mathrm{~A}$ & $19.40 \mathrm{~A}$ & $2.83 \mathrm{~A}$ \\
\hline $\begin{array}{c}\text { Dry sowing with } \\
\text { broadcast }\end{array}$ & $78.07 \mathrm{~A}$ & $398.40 \mathrm{~B}$ & $357.40 \mathrm{~B}$ & $41.00 \mathrm{~A}$ & $19.00 \mathrm{~A}$ & $2.70 \mathrm{~B}$ \\
\hline LSD Value & 2.94 & 34.56 & 39.87 & 3.98 & 1.23 & 0.03 \\
\hline
\end{tabular}

Total number of unproductive tillers $\left(\mathrm{m}^{-2}\right)$ In (Table 1$)$ reveals significant $(\mathrm{p} \leq 0.05)$ effect of herbicides application on total number of unproductive tillers under broadcast and drill sown direct seeded rice. The individual effect of herbicides and sowing methods was statistically significant. However, the interaction between herbicides $\times$ sowing methods was found statistically non-significant $(\mathrm{p} \leq 0.05)$. Application of bispyribac-sodium + benzsulfuron methyl as post-emergence (POST) following PRE herbicides (Ethoxysulfuron ethyl) reduced total number of unproductive tillers $\left(25 \mathrm{~m}^{-2}\right)$. However, the number of unproductive tillers was recorded statistically non-significant under drill sown direct seeded rice. These results corroborate with $[23,28]$ findings.

1000 kernal weight (g)

In (Table 1) reveals significant $(\mathrm{p} \leq 0.05)$ effect of herbicides application on 1000 kernal weight under broadcast and drill sown direct seeded rice. The individual effect of herbicides and sowing methods was statistically significant. However, the interaction between herbicides $\times$ sowing methods was found statistically nonsignificant $\quad(\mathrm{p} \leq 0.05)$. Application of bispyribac-sodium + benzsulfuron methyl as post-emergence (POST) following PRE herbicides (Ethoxysulfuron ethyl) increased the 1000 kernal weight (22). However, 1000 
kernal weight was recorded statistically nonsignificant under drill sown direct seeded rice. The higher 1000-grain weight was due to better kernel development due to lower weed competition and weed population. Similar results corroborate with [29, 28] findings. [30] Reported that higher 1000 kernal weight attributed due to more number of tillers $\mathrm{m}^{-2}$ and less competition between crop and rice plant.

\section{Kernal yield ( $\left.\mathrm{t} \mathrm{ha}^{-1}\right)$}

In (Table 1) reveals the significant $(\mathrm{p} \leq 0.05)$ effect of herbicides application on kernel yield under broadcast and drill sown direct seeded rice. The individual effect of herbicides and sowing methods was statistically significant. However, the interaction between herbicides $\times$ sowing methods was found statistically nonsignificant $\quad(p \leq 0.05)$. Application of bispyribac-sodium + benzsulfuron methyl as post-emergence (POST) following PRE herbicides (Ethoxysulfuron ethyl) reduced kernal weight (3.45). However, maximum kernel yield was recorded under drill sown direct seeded rice. Higher kernal yield attributed due to fact of less weed infestation, more number of productive tillers, number of kernals per panicle, higher kernel weight, bold size of grains and high filled grains per panicle. These results overlaps with $[28,31]$ findings who concluded that better weed management in aerobic rice give higher yield than poor management.

\section{Conclusion}

It has been concluded that Bisypribac Sodium + Bensulfuron methyl (post emergence) followed by Ethoxysulfuron ethyl (pre-emergence) could be exploited to manage weeds under drill sown direct seeded rice. There is a extensive scope to explore the yield potential of aerobic rice by reducing weed infestation under drill sown method of direct seeded rice.

\section{Authors' contributions}

Conceived and designed the experiment: MU Ibrahim \& RN Abbas, Performed the experiment: MU Ibrahim \& RN Abbas, Analyzed the data: MU Ibrahim \& RN Abbas, Contributed reagents/ materials/ analysis tools: MU Ibrahim, RN Abbas \& Z Aslam, Wrote the paper: G Akbar, A Ahmad, M Nadeem, I Yousaf, A Ali \& W Rehman.

\section{References}

1. Chauhan BS, Ahmed S, Awan TH, Jabran K \& Sudheesh M (2015). Integrated weed management approach to improve weed control efficiencies for sustainable rice production in dry-seeded systems. Crop Prot 71: 19-24.

2. FAO (2016). Statistics. World Wheat, Corn and Rice. Oklahoma State University.

3. Sandhu N, Singh V, Sihag MK, Jain S \& Jain RK (2017). Developing climate smart aerobic rice varieties for addressing the problems of water scarcity and global warming. In: Gahlawat S, Salar R, Siwach P, Duhan J, Kumar S, Kaur P (eds) Plant Biotechnol: Recent Advancements and Developments. Springer, Singapore.

4. Mahajan G, Chauhan BS (2013). Herbicide options for weed control in dry seeded aromatic rice in India. Weed Technol 27: 682-689.

5. Jabran K, Mahajan G, Sardana V \& Chauhan BS (2015). Allelopathy for weed control in agricultural systems. Crop Prot 72: 57-65.

6. Wang HQ, Bouman BAM, Zhao DL, Wang C \& Moya PF (2002). Aerobic rice in northern China: Opportunities and challenges. In Proceedings of the International Workshop on Water-Wise Rice Production 8-11.

7. Tuong TP \& Bouman BAM (2003). Rice production in water scarce environments. In: Kijne JW, Barker R, Molden D (Eds.), Water Productivity in 
Agriculture: Limits and opportunities for Improvement. CABI Publishing 53-67.

8. Belder P, Bouman BAM, Spiertz JHJ, Peng S, Castaneda AR \& Visperas RM (2005). Crop performance, nitrogen and water use in flooded and aerobic rice. Plant Soil 273: 167-182.

9. Singh Y, Singh G, Johnson D \& Mortimer M (2005). Changing from transplanted rice to direct seeding in the rice-wheat cropping system in India. In: Rice is Life: Scientific Perspectives for the 21st Century, Tsukuba, Japan: Proceedings of the World Rice Research Conference, 4-7 November 2004, pp 198-201.

10. Nawaz A, Farooq M, Lal R, Rehman A \& Hafeez-ur-Rehman (2017). Comparison of conventional and conservation rice-wheat systems in Punjab, Pakistan. Soil Tillage Res 169: 35-43.

11. Bhushan L, Ladha JK, Gupta RK, Singh S, Tirol-Padre A, Saharawat YS, Gathala M \& Pathak H (2007). Saving of water and labor in a rice-wheat system with no-tillage and direct seeding technologies. Agron J 99: 1288-1296.

12. Bouman BAM, Peng S, Castaneda AR \& Visperas RM (2005). Yield and water use of tropical aerobic rice systems. Agric Water Manag 74: 87-105.

13. Farooq M, Siddique KHM, Rehman H, Aziz T, Lee DJ \& Wahid A (2011). Rice direct seeding: Experiences, challenges and opportunities. Soil Tillage Res 111: 87-98.

14. Upadhyay PK, Kumari E, Sen A, Raha P, Singh RK, Choudhary SK, Singh RK \& Singh Y (2016). Effects of Xanthium strumarium L. extract, anilofos and butachlor on weeds, yield, yield attributes and nutrient uptake of transplanted rice. Bangladesh $J$ Bot 45(1): 227-32.
15. Kumar S, Kumar R, Mishra JS, Dwivedi SK, Prakash V, Bhakta N, Singh AK, Singh SK, Haris AA, Rao KK, Mondal S, Bhatt BP, Singh S \& Yadav A (2017). Evaluation of rice (Oryza sativa) cultivars under different crop establishment methods to enhance productivity, profitability and energetics of rice in middle Indo-Gangetic Plains of Eastern India. Indian J Agron 62(3): 307-14.

16. Hussain S, Ramzan M, Akhtar M \& Aslam (2008). Weed management in direct seeded rice. J Anim PI Sci 18: 8688.

17. Mahajan G, Chauhan BS \& Johnson DE (2009). Weed management in aerobic rice in North Western Indo-Gangetic Plains. J Crop Impr 23: 366-382.

18. Jabran K, Mahajan G, Sardana V \& Chauhan BS (2015). Allelopathy for weed control in agricultural systems. Crop Prot 72: 57-65.

19. Mishra AK, Khanal AR \& Pede VO (2017). Is direct seeded rice a boon for economic performance? Empirical evidence from India. Food Policy 73: 10-18.

20. Mishra JS, Singh VP, Rao AN \& Kumar $R$ (2016). Weed management in major crops. Indian Society of Weed Science and Indian Society of Agronomy.Weed Sci and Manag 160-169.

21. Ganajaxi AVV \& Rajkumara S (2000). Study to develop appropriate techniques for growing direct seeded rice. Adv Agri Res India 13: 197-200.

22. Baloch AW, Soomro AM, Javed MA, Ahmed M, Bughio HR, Bughio MS \& Mastoi NN (2002). Optimum plant density for high yield in rice (Oryza sativa L.). Asian J of Plant Sci 1: 25-27.

23. Khaliq A \& Matloob A (2011). Weed crop competition period in three fine rice cultivars under direct seeded rice culture. Pak J Weed Sci Res 17: 229-243. 
24. Ashraf MM, Awan TH, Manzoor M, Ahmad M \& Safdar ME (2006). Screening of herbicides for weed management in transplanted rice. J Anim Plant Sci 16: 92-94.

25. Jaya Suria ASM, Juraimi AS, Rahman MM, Man AB \& Selamat A (2011). Efficacy and economics of different herbicides in aerobic rice system. Afr $J$ Biotech 10: 8007-8022.

26. Bari MN (2010). Effects of herbicides on weed suppression and rice yield in transplanted wetland rice. Pak J Weed Sci Res 16(4): 349-361.

27. Ramamoorthy $S$, Vilium L \& Panday $P$ (2001). Economics of direct seeding in Asia. Pattterns of adoption and research priorities. Int Rice Res News Left 24: 611.
28. Zhang S, Lovdahl L, Grip H, Tong Y, Yang X \& Wang Q (2008). Effect of mulching and catch cropping on soil temperature, soil moisture and wheat yield on the Loess Plateau of China. Soil Till Res 102: 78-96.

29. Ghosh DC \& Singh BP (2007). Crop growth modeling for wetland rice management and weed management. In: The BCPC International congress. Crop Prod 16: 446-449.

30. Akbar A \& Ehsanullah (2004). Agroqualitative responses of direct seeded fine rice to different seeding densities. Pak J Agri Sci 41: 1-2.

31. Mahmood A \& Cheema ZA (2004). Influence of sorgham mulch on purple nutsedge. Int J Agri Biol 11: 86-88. 